\title{
THE POST-MODERN SCIENTIFIC THOUGHTS OF THOMAS KUHN AND PAUL FEYERABEND: IMPLICATIONS FOR AFRICA
}

\author{
Joseph N. AGBO \\ Senior Lecturer, Department of Philosophy, \\ Ebonyi State University, Abakaliki, Nigeria.
}

\begin{abstract}
Postmodernism is like a spectre hunting the intellectual world, and there is a sense in which the attitude is, first and foremost, against modern science. This essay is, therefore, an expository analysis of the thoughts of Thomas Kuhn and Paul Feyerabend, as classical representations of the postmodern reaction against modern science. The paper argues that the colossal image of science, as well as the idea of a "unity of sciences" had to be jettisoned by postmodernism in order to make way for the relativism and multiplicity of points of view that are symptomatic of postmodern thinking. The paper concludes with some critical reflections of the thoughts of the two scholars, and notes that postmodernism opened the door for the recognition of African ideas and ideals. The implication is that postmodernism not only vitiates the hold exercised by Western European models of reality but equally gives fresh cultural confidence to other modes of cognition, especially in Africa, that have long been pushed to the periphery.
\end{abstract}

Keywords: Modernity, Postmodernity, Transmodernity, Science, Paradigm, Pluri-versality, Incommensurability.

\section{Introduction}

It does appear, and there are cogent reasons for it, that one does not need to be neck deep in logical rigor to argue that there is a sense in which postmodernism is first and foremost a reaction against science; that is, modern science. Understanding the background to and of modernity as well as grasping the core of postmodern thinking, would be enough to let any minimally intelligent person know that the claims of modernity are science-anchored; and consequently, one cannot attack modernity "postmodernly", without at the same time (and simultaneously) attacking science.

When modernity became referred to as the "Age of Reason", it was not an attempt to aver that the periods before it (the ancient and medieval periods, for example) were characterized by "un-Reason" or that "Reason" was, as it were, given birth to during the modern period. No! The Reason in question is the Reason of Rationality, or better stated, logical consistency. In W.H. Newton- 
Smith's lucid and popular book, [The Rationality of Science], he states that science and the scientific community "is taken to be in possession of something, the scientific method, which generates a logic of justification (1). He goes on to aver that at the majestic dawn of modern science, it became the very "paradigm of institutionalized rationality" (1).

This essay argues not only that postmodernism represents a heavy reaction against science, but goes on to unveil the thoughts of Thomas Kuhn and Paul Feyerabend as typologies or classic representation of the postmodern attitude in science. After this introduction, we shall, for the purpose of those who may not be very familiar with the concept, briefly capture the meaning and basic tenets of postmodernism. We would then proceed by exploring what postmodernism had to do to modern science, in order to pave the way for the postmodern conception of science.

Having done the foregoing, we shall then proceed to do an exposition of the thoughts of Kuhn and Feyerabend as examples of the kind of things that postmodernists are saying about science. Although the scholars are not saying the same things (well, no one should expect them to) if we understand the kernel of postmodernism, we would discover that the authors all arrive at the postmodernism shores, eventually, from different departure harbors. After all, postmodernism is not really a school of thought but an attitude to and of philosophizing.

Showing the meaning of postmodernism and its root in modern science and the "how" and "why" the thoughts of Kuhn and Feyerabend are [postmodern scientific attitudes, and how this attitude pluralized the conceptions of reality to the advantage of Africa's modes of cognitions, would be the modest purpose of this essay. Gleaning postmodernism from Kuhn and Feyerabend would be interesting because since postmodernism is an attitude, many postmodernists do not even know that they are. We would, however, end this essay with some critical comments on both the positions of Kuhn and Feyerabend noting briefly some implications for Africa, as well as on the project of postmodernism as a whole.

After all, one of the most crucial challenges faced in the attempts to present African thought system or articulate Africa's conceptions of reality was the accusation that they were "unscientific" (science as modern science). Rationality was ultimately interpreted in Western European terms, with modern science as its legitimate heralder and accredited distributor. And so any view or theory that would not just for the purpose of arguments, but as a matter of fact, debunk the colossal and gargantuan image of modern science should necessarily obbe of interest to Africa. For it would be the dawn of epistemological and ¿ontological freedom. 


\section{A Brief on Postmodernism}

Anyone familiar with postmodernism knows that it is sometimes easier to say what postmodernism is NOT than what it IS. In other words, it would be simpler to say what a postmodernist rejects than what he accepts. What this section would do is to provide a brief information on what postmodernism is, in order to give the reader a key into the scientific thoughts of Kuhn and Feyerabend.

To understand the "postmodern", one needs to understand the "modern"; for what postmodernism rejects are all that makes modernism tick. The "post" in postmodernism has been given two interpretations. While some see it as "anti", others perceive it as "beyond" or "after" modernity. In his paper, "Postmodernism is Existentialist Phenomenology" Jim I. Unah argues that to conceive postmodernism as just anti-modernity is to betray a truncated understanding of what it is and indeed should be. For him, this limited conception is tantamount to saying the "mainstream Kierkegaardean Existentialism had only the task of combating the 'system' and its principal expositor-the professor" (114). For him, postmodernism is "beyond modernity"; that is, an improvement on, not opposition to, modernity.

To be candid, unless we discuss postmodernism in an "unpostmodern" way, we may get stuck with dumbness at worst, and intelligibility at best. This is because discussing postmodernism in a historical or chronological way is not useful, for according to William Spanos, in his "De-struction and the Question of Postmodern Literature: Towards a Definition", Postmodernism is not a chronological event, but a permanent mode of human understanding" (107). For how does one begin to grapple with a term whose proponents even abhor definitions? In his edited book, [The Cambridge Companion to Postmodern Theology], Kevin J. Vanhoozer writes that, those who try to define or even analyze the concept of post modernity usually do so at their own peril; in the first place, no definition is neutral and, secondly, definitions give "totalizing" accounts. Consequently, in Vanhoozer's understanding of what the postmodernists are saying, "a definition of postmodernity is as likely to say more about the person offering the definition than it is of "the postmodern" (1). Unfortunately, while those who agree that they are postmodernists are not in agreement as to what it is they are, some of those whose thoughts tilt towards the postmodern reject the term. Is it any wonder then that in his book, [The Idea of a Postmodern: A History], Hans Bertens comments that the term "postmodernism" and other terms derived from it, such as "postmodern", "postmodernity", "postmodernize", "postmoderrnist", "are not only exasperating, but equally confusing and compounding" (3).

¿ In his essay "Process Thought and Harmony", Warayuth Sriwara Kuel says ¿that despite the ambiguous and multiple meaning of the word "postmodern", the term has become a "specter" roaming around the academic world, since "more 
and more intellectuals from various fields like to use the word to label their ideas and positions" (101). However, for Lawrence E. Cahoone, in [From Modernism to Postmodernism: An Anthology] gives 3 main connotations that philosophical reflections on postmodernism revolves around, and then argues, in my opinion, falsely that "all three reactions are misguided. Certainly the term 'postmodern'... can be subjected to easy riddicle as hopelessly ambiguous and empty" (1). The 3 connotations of postmodernism identified by Cahoone are: one, it refers to the last escape from authoritarianism, colonialism, racism and domination which are all legacies of modern European thought; two, it connotes the attempt by intellectuals on the Left to destroy Western Civilization; and three, a collection of hermeneutic writers and scholars whose obscure presentations make it look as though they are not saying anything. What is significant, for us Africa, the Cahoone's classification is that the first one appears to be the major goal of postmodernism- an escape by those that have long been on the periphery of Western intellectual domination. If postmodernism is concerned as a "going beyondness" hardly will it be of interest to us as Africans. The second characterization appears to be a reaction by Western intellectuals to paint postmodernism in bad light. And on the fact that some postmodernists appear obscure, I think it is part of the protest character of postmodernism itself- it is a reaction against the simple and naïve progressiveness of modernity

I do not think, however, that we should get trapped or lost in the labyrinth of the excessive and polemical "scholarshipism" of postmodernism. For if postmodernists disagree about many things, they would never disagree on the fact that postmodernism is a rejection of absolutes, essences and foundations. Jean Francios Lyotard, one of the contemporary proponents of postmodernism captures its meaning succinctly when he says in [The Postmodern Condition], that postmodernism is "incredulity towards metanaratives" (109). By this, he means that we should abandon all attempts we make to find a grand, universal, trans-historical, transcultural scheme, paradigm or algorithm with which we can legitimize knowledge or justify the choice of one theory over another. Having abandoned the search for a grand norm, we are then left with heterogeneous, pluralistic multiplicity, incommensurable differences. No wonder James Morley, (UNAH 117) opines, as a corollary, that postmodernists "see the dissolutions of distinction, the merging of subject and object, self and other... a sarcastic playful parody of Western modernity and a radical anarchist rejection of all attempts to define reality or re-present the human subject". Postmodernism rejects the Nessential pillars of the modern period: Reason (Rationality) and Method - (Science). In his [Multicultural Citizenship], Will Kymlicka writes about "the oodebate between...rationalists and postmodernists" (153), thereby juxtaposing ¿postmodernism and rationalism. 
Post-modernism, therefore, is a calculated and frontal rejection of the various rationalist and modernist, models of interpretation of reality, especially those ideas that lay tenacious grip on the immutability of knowledge, truth and essentialism. Post-modernism sees reality as a social construct, given meaning only within the context of certain defined cultural conditions. For them any reality not defined and characterized by communities or societies, based on their cultural particularity, is no reality at all. Consequently, post-modernism rejects all ideas and theories that lay claim or essay to be cross-cultural; such as Marxism, Humanism, Existentialism, Socialism, Essentialism, Darwinism, Creationism, Evolutionism, Spiritualism, Religionism, etc. These theories are regarded as being authoritative and possessive of absolute truth, and therefore, unable to access reality.

Writing in an essay titled, "Richard Rorty and the Postmodern Rejection of Absolute Truth", Dean Geuras quotes Rorty (Geuras calls Him "postmodernism's most-gifted defender") as saying that there is no "Skyhook" which removes us from our subjective condition to reveal any reality existing independent of our perception. Recall that in his earlier book [Philosophy and the Mirror of Nature], Rorty had laid the blame of the "evils" of the modern period on Kantian Foundationalism, and argues in chapter 3 "The Idea of a "Theory of Knowledge" that it was this attempt to "Theorize" on knowledge that created the castrating hegemony of modern epistemology, to which postmodern hermeneutics stands opposed. For Rorty, therefore:

\begin{abstract}
Hermeneutics is an expression of hope that the cultural space left by the demise of epistemology will not be filled, that our culture should become one in which the demand for constraint and confrontation is no longer felt. The notion that there is a permanent neutral framework whose "structure" philosophy can display is the notion that the objects to be confronted by the mind, or rules which constrain enquiry, are common to all discourse, or at least to every discourse on a given topic. Thus epistemology proceeds on the assumption that all contributions to a given discourse are commensurable. Hermeneutics is largely a struggle against this assumption. (315-316)
\end{abstract}

The ambivalence between epistemology and hermeneutics is not strictly our concern here. I have addressed it more closely in my essay, "Science and the 'End' of Epistemology". But our interest is on the fact that the postmodernists Msee the modern period as the dawn of Reason and Science, and the grand theorizing led to, as the [Oxford Dictionary of Philosophy] puts it, "a naive and osearnest confidence in progress... in objective and scientific truth", the result is

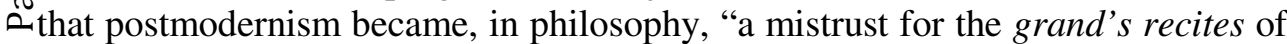
modernity, the large scale justifications of Western society and confidence in its 
progress visible in Kant, Hegel or Marx or arising from 'utopian' visions of perfection achieved through evolution, social improvements, education, or the deployment of science"(294-5).

A mere cursory glance at postmodernism would reveal that it does appear that if modernity would survive, if one could still hoist what James F. Harris, in his challenging book, [Against Relativism: A Philosophical Defense of Method], "the tattered flag of modernity" (4), then we must save modern science and the epistemological foundation that stands at its philosophical base. Otherwise, the collapse of science marks the collapse of the Modern Enlightenment project. But that's not the fundamental desire of postmodernists. They want to, as Rorty puts it, open "cultural space" to multiple and plural criteria of justification and legitimization. At this point, we must move on.

\section{Postmodernism and Modern Science}

I must observe from the onset that before what we come to know as modern science, whatever was baptized "scientific" or "science" was mainly developed from the philosophy of the encyclopedic-minded Greek philosopher, Aristotle. Most of what later became the concerns of Astronomy were based on Aristotle's musings on theories. As a matter of fact Claudius Ptolemy's geocentric conception of the universe (that the Earth was the centre of the solar system, and all other planets; including the Sun, revolved round the Earth) was directly deduced from Aristotle's theories. Ptolemy, an astronomer who did most of his works in Alexandria, Egypt, had to publish a work with the title The Almagest in A.D. 150 .

The geocentric theory was the dominant view of the universe for several centuries. As a matter of fact, it was not until 1543 when a Polish monk named Nicholai Copernicus proposed a heliocentric theory, according to which the Sun was seen as the centre of the Universe, with all other planets, including the Earth, revolving round the Sun. In his essay, "The Fall of Aristotelian and Ptolemaic System", Enyimba Maduka notes that one of the reasons why the Copernican system overthrew the Aristotelian/Ptolemaic system was that "Copernicus geometrically placed the sun at the centre of the universe and had the earth orbit it, thus, reducing the unweidling number of epicycles from 80 to 34" (210), a claim he attributes to Chris Butler. Of course, as at that time, the idea of a moving Earth was absolutely mind-bogging to men without secular mentality, especially religious bigots. Indeed, it was branded "Heresy". And even for those

$\checkmark$ who understand the veracity of the Copernican position, it was thought at that time that the planetary motion was circular. However, that was to change later Eowhen the young mathematician, Johannes Kepler (1571-1630), discovered an ¿elliptical rather than a circular orbit. 
For the postmodern attitude in science to be proposed, propagated and grounded, certain conceptions and perceptions of the scientific enterprise had to be jettisoned. That science is a rational endeavor is a view vigorously and rigorously pursued by the Austrian philosopher of science, Karl R. Popper (19021994). This accounts for why he spent a large chunk of his 92 years, resources and works trying to distinguish science, not just from non-science, but equally from what he called "pseudo-science". His battle with historicism, especially of the Marxian type, is well expressed in his popular works; notably, [The Poverty of Historicism] and the two volumes of [The Open Society and its Enemies], as well as [Conjectures and Refutations]. Popper argues that science makes progress by "bold conjectures and the critical search for what is false in our various competing theories"(52) which, for him, materialist dialectical method is not capable of doing. He, therefore, holds Marxism guilty of what he called "reinforced dogmatism". In [Conjectures and Refutations] for example Popper writes that:

Hegelian dialectic, or its materialistic version, cannot be accounted as a sound basis for scientific forecasts. Thus if forecasts based on dialectic are made, some will come true, and some will not. In the latter case, obviously, a situation will arise which has not been foreseen. But dialectic is vague and elastic enough to interpret and to explain this unforeseen situation just as it interpreted and explained the situation which it predicted and which happened not to come truth. (333)

Our interest here is not really on Popper's intellectual battle against Platonism, Hegelianism or Marxism. We are citing him because he represents a classical expression of what modern science represented: methodological exactness and the dogged search for truth.

Consequently, the very first thing we notice about postmodernism in science is that it had to attack the colossal image of science, it had to debunk the view not only that rationality is the basis for modernity, but equally the view that sees in modern science the best representation, glorification and expression of that rationality! The issue gained currency that modern science cannot become the ground for the justification of reality when it rests on grounds that themselves need to be justified. In other words, how can we accept (or justify the correctness of) the measurement taken with the ruler (or metre, or tape) of modern science when we are asking for the justification for using the ruler, in the

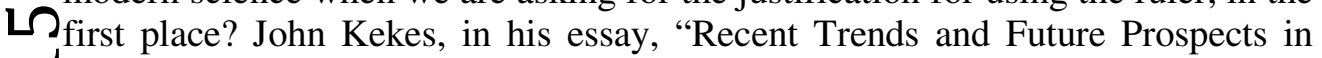
DEpistemology", explores some of these arguments.

$\infty_{0}^{\infty}$ The next edifice that had to be pulled-down to pave way for the postmodern conception of science was the idea of the "unity of science", that is, that "science is science" irrespective of what the subject-matter is. For instance, 
at inception, and in order to be listed in the fashionable and "respectful" science "hall-of-fame", what became known as "social sciences" wanted to ape the method of physical sciences hollow. Of course, at the dawn of modernity in the $17^{\text {th }}$ century, when the idea of a prescribed methodology, was muted, it was possible to even imagine it because there was only one fully developed science, physics, or more specifically Newtonian Mechanics. Newton was so permeating in the modern period that his six-step of scientific enquiry was for long the dominant "method of science". Bertrand Russell, in [History of Western Philosophy] makes a parody of the Biblical story of the beginning of all things. In a poetic expression Russell writes: "Nature and Nature's laws lay hid in the dark, God said, Let Newton be', and all was light"(523) for Russell "almost everything that distinguishes the modern period from earlier centuries is attributable to science, which achieved its most spectacular triumph in the seventeenth century (512).

The purpose of the postmodern rejection of a "unified science" is postmodernly simple: a unified science is an attempt to create a grandstand where all sciences would converge and that would lead to the demand for a single standard for legitimization. The result would, obviously, be a regimentation-the emergence of a trans-scientific, narrative for all the sciences. Yet, but what the postmodernists want is a multiplicity of methods; that is, let each science or scientific enquiry articulate its methods and procedures in line with its subjectmatter.

Having laid these brief foundations, I think that the stage is set for us to discuss Kuhn and Feyerabend as exemplars of the postmodern attitude in science.

\section{Kuhn on Scientific Revolutions}

A clearer and better understanding of what we have called "postmodernism in science" now begins with a consideration of the thoughts of Thomas S. Kuhn. Kuhn begins his ground breaking book, [The Structure of Scientific Revolutions] by beaming a critical searchlight on the colossal, or rather bogus, image of science as the paradigm of institutionalized rationality. With an exploration of the history of science and an examination of the actual practice of science, Kuhn's discovery and conclusion was that this towering image can be debunked.

The radical form of epistemological relativism usually associated with and charged to Kuhn emanated from the theory of the incommensurability of paradigms which he espoused. In the opinion of Harris, although many of the Oissues that have led to the rise in the plethora of views about the image of science $\checkmark$ have been raised earlier by people like David Hume and Charles Pierce, "these Eodebates are now explicitly formulated within the philosophy of science, and the $\widetilde{\sim}$ stakes certainly have been raised. On the table now are the very rationality of science itself and the viability of epistemology as a philosophical enterprise. The 
ugly specter of relativism is raised, Skepticism is clothed in new sheep's clothing, and science is in danger of becoming... just another ideology" (73).

After laying the foundation of his discussion by throwing a swipe at the image of science via a consideration of the history of science and what scientists themselves do, Kuhn proceeds by considering what he calls the period of normal science. This period is the period when the members of a particular scientific community share a common model or paradigm; that is, when every member of that community refers to or works from a common "theory laboratory". Many commentators find Kuhn's idea of paradigm very vague and too elastic. In fact, in their edited work, [Criticism and the Growth of Knowledge], Imre Lakatos and A. Musgrave (59-90) quotes one Masterman as identifying about 22 different senses in which Kuhn used the term "paradigm". We shall get back to this challenge later when we would be carrying out a concluding critique in this essay; but our major concern here is that understanding the idea of a "paradigm" is crucial to understanding Kuhn's conception of "normal science". Early in The Structure of Scientific Revolution, Kuhn refers to paradigms as what "provide models from which spring particular coherent traditions of scientific research" (10), but later in the book (174- 190), he launches into a fuller expression of the meaning (s), content(s) of paradigms. Kuhn captures the relationship between paradigms, the scientific community and normal science, in the following words:

The study of Paradigm ... is what mainly prepares the student for membership in the particular scientific community with which he will later practice. Because he there joins men who learn the basis of their field from the same concrete models, his subsequent practice will seldom invoke overt disagreement over fundamentals. Men whose researches are based on shared paradigms are committed to the same rules and standards for scientific practice. That commitment and the apparent consensus it produces are prerequisites for normal science, i.e., for the genesis and continuation of a particular research tradition. $(10-11)$

This kind of "gentleman's agreement" and respect for a particular paradigm (it is not a legislated action, there is some sought of voluntary compulsion to have a feeling of not just belonging but equally belongingness to the "exalted scientific community), and the continued reliance on that paradigm to solve problems within the scientific community, clearly define the period of normal science. As Newton-Smith correctly captures it, "during this period, the energies of members - of the community are given over to solving Puzzles defined by the paradigm, Dowhich is itself based on some significant achievement" (107).

2 He, however, argues that because Kuhn's use of the term "paradigm" is "vague", it would be hard to suppose that the periods of what Kuhn called 
"normal science" can be clearly defined. However, as to whether there can be periods of agreement, by a scientific community, on both theoretical assumptions and on the problems to be solved, there can be no doubt. If anomalies are detected during normal science, they are treated as problems to be solved rather than as something that refutes the theory.

According to Kuhn, there would come a time when the number of unsolved puzzles as well as the anomalies would mount. This would automatically result in a crisis of confidence by the sharing scientific community. The agreement that was the basis for the sharing of the paradigm would begin to break as alternative theories are articulated. At this period, when faith is lost in an existing paradigm, a revolution, analogous to political revolution, would occur within the scientific community. In drawing this analogy with political revolution, Kuhn argues that under "normal" political circumstances, there is agreement on the means of decision making, but in revolutionary situations, some individuals attempt to change the society by force through the creation of a new framework for decision making. In Kuhn's own words:

As in political revolution, so in paradigm choice-there is no standard higher than the assent of the relevant community. To discover how scientific revolutions are affected, we shall, therefore, have to examine, not only the impact of nature and logic, but also the techniques of argumentative persuasion effective within the quite special groups that constitute the community of scientists. (94)

The implication of the above is that historical and sociological factors are indispensable in science. Propaganda becomes a crucial factor in science. As Kuhn again says; "the normal scientific tradition that emerges from scientific revolution is not only incompatible but often actually incommensurable with that which has gone before (102).

The focus on paradigm is about the most important contribution made to the philosophy of science by Kuhn's Structure of Scientific Revolutions. From a somewhat "preparadigmatic" era, Kuhn characterizes a period of agreement among the scientific community on the model for methods, techniques and questions in science. According to Harris, 'the single most-important and, at the same time, one of the most controversial aspects of Kuhn's science is that it is paradigm based" (76).

That an aspiring scientist must be aware of the paradigm of a scientific community, that only there from can he consciously proceed if he wants to be a fruitful and accepted member of that community, and that the loss of faith in a Doparticular shared model (paradigm) results in a situation similar to that of the Biblical "to your tents Oh Israel", appear to be Kuhn's innovative position. It is in the emergence of a new paradigm after the revolution (let us call it Normal- 
Science-Next, NS-N) that our postmodern interest in Kuhn lies. According to Kuhn:

If two men disagree, for example, about the relative fruitfulness of their theories, or if they agree about that but disagree about the relative importance of fruitfulness and say, scope in reaching a choice neither can be convicted of a mistake, nor is either being unscientific. There is no neural algorithm for theory- choice, no systematic decision procedure which, properly applied, must lead each individual in the group to the same decision. (199-200)

The Kuhnian position has been perceived as post-modernist or post-positivist because of the way he characterized the nature of the occurrence of the revolutionary shift from the old to the new paradigm. Kuhn has characterized that change as a "sudden and unstructured event" and it would appear that reasoning oneself into a new paradigm is impossible since Kuhn says that the guiding motivation for accepting the new paradigm "can only be made on faith". Science becomes another ideology like religion. For him, "proponents of competing paradigms are always at least slightly at cross-purposes" (148). James Harris clearly explains Kuhn's position in the following words:

The new paradigm which replaces the old one during a scientific revolution is, according to Kuhn, "incommensurable" with the old paradigm, that is: since the new paradigm "necessitates a redefinition" of the old and since the standards and criteria for the evaluation of paradigms are internal to the paradigms, it follows that the change from the old paradigm to the new one cannot come about by appealing to some neutral criteria or method of paradigm selection. Perhaps most importantly, the replacement process is not the old, familiar falsification/ verification process from science before the revolution where certain data might either falsify or verify one paradigm or the other. Since the new paradigm is incommensurable with the old, the process of abandoning the old in favor of the new cannot be a gradual, logical or "scientific" process based upon evidence or some form of reasoning. (78)

Let us try to itemize Kuhn's position from what Harris has just said: the emergence of a new paradigm for NS-N is seen as postmodernist because: one, Othe new paradigm was not a logical or systematic (or even dialectical) deduction from the old paradigm. This means that the question of building from the past ¿aupon which science thrives does not arise; Two, the new paradigm was not selected from a kind of neutral pool of paradigms whose legitimacy is vouched for by the members of the scientific community. In other words, there is no 
"respectable" or "respected" paradigm or class of paradigms that the scientific community accepts (or had accepted), and which the community invests with the toga of finality or authority when it comes to paradigm choice, no paradigm adjudicator with a mandate such as: "if there is a disagreement on paradigms choice or if there is loss of confidence in or failure of an existing paradigm, provide a new one". A third reason for the postmodernist characterizing of Kuhn is because the new paradigm that emerges from the revolutionary period is not based on the old principles of falsification (a la Popper) or verification (a la Logical Positivism).

However, a major question needs to be asked at this point, especially as it relates to the third reason given above: why must the failure of the new paradigm to have its base on Popper's Falsification and the Verification principle of logical positivism become an issue? Are the Logical positivists and Popper the only propounders of scientific methodologies? Well, to address the matter straight away, we need to remember Popper's frontal important role in perceiving science as a rational enterprise. He was a leading figure in the conception of the place of science in the overall development of the twentieth century. When it comes to Logical Positivism, the place of the movement in the growth of science is more of a reference point in almost all discussions on and about science. In his small but insight-lending book: [The Philosophy of Logical Positivism and the Growth of Science], G. O. Ozumba reminds us that the movement marks "a turning point in the history and development of ideas" (9), and notes the fact that the movement concentrated on the "observable" and the rejection of metaphysics. But if Ozumba did a critique of logical positivism, Harris was more critical of the project of the logical positivists. In fact, according to Harris, it was the failure of the project of logical positivism that opened up the modern period to a barrage of punches (of criticism) and then inaugurated the postmodern relativistic alternative. For Harris, the disappointment of a few men promising a lot to many (with their Verification Principle) and failing to deliver, just led to the belief that the last stronghold of modernity has collapsed (7). The issue here is not really on logical positivism. We rather want to provide explanation for why the failure of Kuhn's analysis to conform to the Verification Principle should become important. The objectivity usually claimed for the Verification Principle is denied in Kuhn since the criteria for judging or evaluating each paradigm is internal not external to it.

However, before we proceed to look at Feyerabend, it is important to briefly look at the so-called "shift of position" by Kuhn. We need must note that every (philosophical) position taken by a scholar is read, studied, analyzed and oninterpreted. The thesis of the "incommensurability of paradigms" put forward by ¿Kuhn was interpreted to mean that he has voted for "irrationality" and of courses, radical relativism, with the legendary difficulties associated with them. In his 
essay, "Reflections on My Critics", Kuhn attempts further explanation and clarification of his position when he writes that:

My critics respond to my view on this subject (the incommensurability of paradigms) with charges of irrationality, relativism and the defense of mob rule. These are all labels which I categorically reject even when they are used in my defense... To say that, in matters of theory choice, the force of logic and observation cannot in principle be compelling is neither to defend logic and observation nor to suggest that there are not good reasons for favouring one theory over another. (234)

Relativism of the radical incommunicating type as well as irrationality juxtaposed with the Western conception of rationality (as logical consistency), is so emptily and negatively construed that no Western scholar would want to proudly and brazenly be associated with them, because they do not see the complementarity between the rational and the irrational, the relative and the objective. So, no one needs to blame Kuhn for wanting to wash his hands off such associations, either positively or negatively.

Kuhn, in this shift of position is interpreted as suggesting simply that there is no "neutral algorithm for theory choice" (200) and not that one cannot proffer "good reason" to justify the preference of one theory over another. Understood in this latter sense, Kuhn, it is assumed, would not be seen as a brash irrationalist. In the opinion of Harris, Kuhn, in the explanation for the so-called shift, wants to retain the notion of incommensurability but in a "moderate" (89) and "weakened" (90) way. We must pause now on Kuhn (we would return to it when we carry out a critical conclusion of this essay) to consider another iconoclastic analyst of the image of science, Paul Feyerabend.

\section{Feyerabend and the two Pillars of Modern Science}

Maybe it was intentional, maybe it was not; but when Paul Feyerabend wrote his two most popular books, [Against Method] (1975) and [Farewell to Reason] (1987), he struck two bomb-like blows at the two Pillars of modernity: Science and Reason. When Feyerabend's book, [Against Method] appeared, it sought to provide equal access to questions of method and perception of result for other traditions such as astrology, Witchcraft and traditional medicine. Newton-Smith called [Against Method] the most "lively or entertaining critique of the scientific method" (125). For him the work could have been titled [Against Received Opinion]. For Feyerabend, there is nothing sacrosanct or special about science because there is no clear difference, in method and result, between science and ๘other traditions.

Although Feyerabend usually rejects the influence of Karl Popper on him, it is not difficult to observe that influence. After all, both of them, at one 
time, taught at the London School of Economics and Political Science. What Feyerabend opposes when he speaks of "method in science is the idea of selecting, adopting or relying on a system of rules that would generate a logic of justification or guiding compass that would help scientists to legitimately make theory choices. Science thrives and makes progress by claiming that there is such a universal notion of human understanding and that if humankind is able to grasp it, then progress can be made at all fronts In [Farewell to Reason]."Feyerabend pejoratively describes such claims as "conceited, ignorant, superficial, incomplete and dishonest" (25). In a yet to be published essay, "On the Diction of Postmodernists" I have not only discussed and analyzed a plethora of such adjectives, I have equally suggested reasons why postmodernists use such derogatory, debasing, confrontational and polemic terms when discussing modernity and its harbingers.

Newton-Smith appears to summarize Feyerabend's project in [Against Method] when he says that he (Feyerabend) "stands against the venerable tradition of searching for a system of rules which it is held ought to guide scientists in the business of theory choice" (126).

Feyerabend does not accept the doctrine or principle of Cummulativism, according to which scientific knowledge is acquired piecemeal through observation, formulation of theories and experimentation. Cummulativism, as Princewill Alozie explains, in [History and Philosophy of Science]:

If $\mathrm{T} 1$ is an accepted scientific theory for a given period and there emerged a new theory $\mathrm{T} 2$ which could explain things that $\mathrm{T} 1$ could not explain; as long as T1 was empirically confirmed initially, then T2 will necessarily include $\mathrm{T} 1$. But $\mathrm{T} 1$ and $\mathrm{T} 2$ are about a given phenomenon. If there is a third theory, $\mathrm{T} 3$ which has more explanatory power than the first two, then we shall be having series is knowledge that are linked up thus: T1-T2-T3-. (155)

In rejecting the cumulative model, Feyerabend argued that the words used in formulating the different theories would have had changes in their meanings and so the theories cannot be linked with themselves in the attempt to address a particular phenomenon. This rejection of piecemeal acquisition of theories is similar to Kuhn's view that a new paradigm is incommensurable with an old one.

We must remember that Feyerabend's attack on science is on the concept of method. Of course, there are two activities which methodological concerns in science usually cover: First, what rules are there for the discovery of theories and what principles can we objectively use to justify our evaluation of rival theories. OIn other words, if we want to discover theories in science, are there laid-down rules to be followed in doing so? Second, when it comes to preferring one theory over another or evaluating the explanatory content of two or more theories are 
there principles (as fundamental truths) that we can possibly rely on to justify our choice? These are the two broad issues that are traditionally held to be the focus of methodological concerns in modern science.

Not only does Feyerabend reject a distinction between these two activities of discovery and justification; he proceeded to reject that science has a method. For him, in [Against Method]:

The idea of method that contains firm, unchanging and absolutely binding principles for conducting the business of science meets considerable difficulty when confirmed with the results of historical research. We find then, that there is not a single rule, however plausible, and however grounded in epistemology, that is not violated at some time or other. (23)

Feyerabend rejects the view that science is a rational activity; he debunks the claim that science, in method and result, can be clearly distinguished from myth, religion, philosophy, astrology and even ideology. The charge of "epistemological anarchism" is usually leveled against Feyerabend. This is sequel to his claim that:

It is clear then, that the idea of a fixed method or of a fixed theory of rationality, rests on too naive a view of man and his social surroundings... it becomes clear that there is only one principle that can be defended under all circumstances and in every stage of human development. It is the principle anything goes! (27-28)

The charge of "mob-psychology", "cognitive egalitarianism", "anything-goes relativism" etc., have been variously leveled at Feyerabend and his postmodern colleagues in the philosophy of science. But no matter the charge, Feyerabend's focus should not be forgotten: that there is nothing special about science. As he says again that logic and arguments cannot make science any better than it is. In another monumental later book, [Farewell to Reason], Feyerabend says that "the idea of a science that proceeds by logically rigorous argumentations is nothing but a dream (43)".

What Feyerabend means by "anything goes" is not that there are no methods which sciences in various forms or which scientists use. What he is against is the thought of making or perceiving science as rationality per mexcellence, which contains one method. Again, he says that his argument does Not directly encourage the proliferations of methods or theories. He later argued odhat all he had done was to show that the rationalist cannot possibly exclude ¿proliferation of methods. He suggests that the Galilean example should be imitated: he did not succumb to the paradigm or method of his day. That way, 
progress was ensured. No wonder Newton-Smith refers to Feyerabend as "a paradigm case of ... a non rationalist" (126).

What Feyerabend appears to be arguing for can be expressed thus: "Hey", dear rationalists, would you by adopting your rationalist method/theory also (at the same time and automatically) exclude someone else from holding on to and adopting a method/theory that does not conform to your criterion (or criteria) of rationality? In other words, the rationalist cannot simply by adopting a position assume that the mere fact that he took that position would prevent, stop, prohibit or disallow the possibility of holding on to a counter rational position.

In [Science in a Free Society], Feyerabend disagrees that proving that a system is inconsistent, as the rationalists do many times is even a proof that there is something wrong with the system since even inconsistent theories, have brought about progress in science (210-211). He further posits that this desire and demand for rules of logical consistency without exceptions would end up becoming indefinite and, consequently embracing of everything (128).

At the end of the day, Feyerabend was overall interested in showing that science is just one ideology among many others. He chose to critically strike at the two fundamental pillars of modern science: Method and Reason (Rationality)!

Although, science has laid claim to several technological breakthrough, the consensus of opinion appears to be that science (and its method) is only but one cognitive approach to the vast array of reality. As Alozie concludes for us:

The history and method of science give it the colour of any other ideology or world-view. Some of the claims of science are similar in character or "truth-content", to myths and religion. There is the excellence and superiority of science and also the imperialist powers who do not allow other cultures to make their contribution to the body of knowledge that can improve the world. Might appear to be right. In quite a large measure, Paul Feyerabend is correct in his criticism of how science is perceived... it has been discovered that the word "science" may not have a great technological value. Science has to be co-joined with technology for political and economic reasons. The under-developed and impoverished majority of world population need to learn that there is an ideology which is superior to their various religions, myths and cultural values. That superior ideology is science. (160) umeans "to know", which is the same thing as "episteme", from where the term ๘" "epistemology", a major branch of Philosophy, is derived. Science, as Alozie has just noted had to become "science and technology" in order to become a practical 
discipline. As "science", building theories and discovering laws are the central concerns, but as "technology", it would involve lighting bursen-burners and mixing chemicals.

\section{Conclusion: Implications for Africa}

Fortunately, the only thing being concluded here is the text of this essay, the issues at stake here are not being concluded (and may never be). There are so many things involved in addressing the thoughts of Kuhn and Feyerabend, on the one hand, and the debate between postmodernists and modern science/rationality, on the other. We have only used Kuhn and Feyerabend as examples of the postmodern attitude to science. Attempting to grapple with the complexities of the issues would be unnecessary, even impossible, here.

While Kuhn considered the history and actual practice of science as the basis for rejecting the bogus image of science, Feyerabend argued that in terms of method and result, modern science is just one way of cognizing reality, among many others. No doubt, like all other issues that domiciles within the philosophical discourse, they have many supporters and critics, but we won't go into much details to consider the (de)merits of each. A fundamental question needs to be asked at this point: what really was the problem with modern science that makes postmodernism get so much attention, even when one disagrees with it? In other words, is the postmodern attitude in science (and postmodernism in general) just some gibberish, some play with words?

This way of interpreting or understanding the word "science" is too exclusive, too restrictive for participation by other cultures. But what is "science" but an articulation of an understanding of the Laws of nature? And are we concluding that only the Western world had the capacity to understand nature? It is also the case that when tools or equipments are fashioned or adapted, in line with this understanding, in order to confront the environment and improve humankind's existence, it is called "technology". Neither science, nor its practical output, technology, is an exclusive preserved of any culture. Having set the pace, as a result of colonial conquest, the West has made those of us in Africa to get into a desperate rat race to "prove" that we "have" philosophy, science, religion, history, etc in line (unfortunately) with the conceptual schemes of the West.

Newton-Smith has argued that "Feyerabend... is much more radical in his critique of rationalism than Kuhn. Kuhn holds that there are rules held in ऽcommon by all members of the scientific community" (126). But from history, Npractice and results of science, we have agreed to a large extent, that the odheorization, systemization and Kant-ization of knowledge in the modern period ¿led to a visceral regimentation of reality. Modern science appeared not only to have appropriated knowledge, but actually "arrested" and "detained" it in the 
intellectual and scholarly "Concentration Camp" of Western bookish, scholarship, nay school-ship form. Anyone that wants to have access to knowledge must have to pass through the guarding-Gestapo of an imposing Epistemology, the allusion to Kant here is crucial because he is the source of the foundationalism that postmodernists reject. In my essay "A Critique of the Critical Philosophy of Immanuel Kant", I have discussed some of these issues, especially with regard to Rorty's claim that it was Kant that made epistemology "self conscious"

Lyotard has argued that knowledge is broader than science, since scientific knowledge is "narrative" which means that it appeals to a single, grand scheme (78). For him, science rejects other narratives, branding them "fables, myths and legends". But the postmodern condition contains measures that build competence and they are derived from culture and custom. Legitimization, therefore, must be based on socio-political and on ethnocentric grounds. The result is that epistemology becomes sociology. For Lyotard, therefore, "all we can do is gaze in wonderment at the diversity of discursive species, just as we do at the diversity of plant and animal species (80).

Of course, when we use "science" here, we mean specifically "modern Western science", because "science" is not a Western word. It is a way of understanding or explaining reality, and it exists in all cultures. Without getting into the semantic battle of what it is for any concept to be "African" (see for instance, S.B. Oluwole's) "the Africanness of a Philosophy", J.I Unah's "Can a Work Be Both African and Philosophy", and J.O. Oguejiofor's "How African is Communalism"), I want to suggest that Jonathan O. Chimakonam's new, courageous and insight- lending book, [Introducing African Science...] is a work given birth to by the spirit of multiplicity and plurality championed by the postmodern attitude. What Chimakonam refers to as "letting other cocks crow besides one", a condition which is perceived as a transgression of "the boundaries of reason and the custom of the salient community" (3), is an allusion to and opening of what Rorty had earlier called "cultural space".

In my paper "Africa Within the Globe: Confronting the Parameters of Cross-Cultural Philosophy", I had argued that those of us in the African continent, and others in the Diaspora committed to Africa's course, appeared to have shot ourselves in the foot when we began to talk of "African Philosophy" instead of "philosophy in Africa". For philosophy is a universal endeavor and activity which exists and is carried out anywhere Homo sapiens dwell. The Odebate as to what makes anything "African" appears to be unresolved, since Ngeography, birth and color may not be very helpful. The issue at stake here is not odhese debates. The point of interest here is the fact that postmodern hermeneutics $\widetilde{c}$ created the pedestal for the thoughts of different cultures to be displayed, not to be judged against the backdrop of Western cannon of rationality, but to be 
appreciated and described within the context of its own natural habitat. In my essay, "The Spectacles of Inter-cultural Philosophy: Same Frame, Different Lenses", I have discussed the possibility; goals, need and challenges of an intercultural philosophy. At least, the possibility of an intercultural philosophy is a pointer that we do not have to, as it were, be conquered by the radical, noncommunicating relativism that postmodernists often brandish.

Although many have regarded as gross distortions" the interpretation that Kuhn's positions are skeptical and relativistic, it is obvious that his claim of emergence of competing paradigms at the dawn of "revolutionary Science", aligns him with the plurality that is the hallmark of the post-modern era. No wonder Robert Baun and Feyerabend, in "Popper, Kuhn, Lakatos: A Crisis of Modern Intellect" regards as "intellectual anarchism" any position that could be interpreted as being the end of the reign of Reason (181).

Now, does Kuhn's claim that the criterion for problem solving is INTERNAL to a particular paradigm also mean that the criterion for selecting or choosing one paradigm over another is also internal? One of the mercurial philosophers of science of our era, Israel Schefler, in his book, Science and Subjectivity, said, and rightly too, that the kind of puzzles and their solutions may, and in fact does differ, from paradigm but it does not mean that one cannot reasonably argue over paradigms (202). Kuhn's famous "irrationality thesis", therefore, cannot be defended. The limitations imposed by the incommensurability of paradigm are enough for the acceptance of the impossible rational theory choice. For Kuhn, that limitation makes it both difficult and impossible "for an individual to hold both theories in mind together and compare them point by point with each other and with nature. That sort of comparison is, however, the process on which the appropriateness of any word like "choice" depends (Kuhn, The Structure..., 168).

Kuhn had hinged his decision on the incommensurability of paradigms on the view that the concepts used in formulating the paradigm have different meanings and applications. Kuhn's popular example of what he means is shown in his claim that when Copernicus' heliocentric view of the solar system was accepted in place of Ptolemy's view, it was made possible via the denial of the title of "Planet" to the Sun, while it was not denied to the Earth. (Kuhn, The Structure.... 128). That way, there was a change in the very meaning of the concept "planet".

Those who accuse the postmodernists of playing with words or relying heavily on analysis of worlds forget that we communicate our thoughts with words or language. When it is argued that the postmodernists reject the very idea Nof "truth" (Kuhn, for e.g., SSR, 170), it is truth absolutized, regimented and oxcanonized. However, in the essay "Reply to Criticism", Feyerabend clearly $\approx$ argued that the notion of incommensurability is actually independent of the theory of Invariance in meaning (231-234). Andrew Sayer, in his 
"Postmodernism and the Three 'pomo' Flips" says that in the final analysis, postmodernists end up "refusing all talk of truth and falsity, denying any kind of relationship between thought and world" (69)

This type of attack on and defense of relativism (especially) is popular and available within scholarly circles, so much so that they are beginning to sound like cracked records. For example, against the type of criticisms pursued by people like Sayer, Jonathan Chua Yi in his paper "A Postmodern Defense of Thomas Kuhn" argues that:

\begin{abstract}
Despite showing all signs of belonging to the postmodern camp, Kuhn can be defended by arguing that relativism is necessitated by the way human understanding is itself structured. Although critics like Andrew Sayer might want to argue that reliable knowledge is still possible, it remains an unfortunate "truth" that even the standards of scientific objectivity are socially determined by the prevailing paradigm of science. What is important is not to ignore postmodernism or take a defeatist attitude toward it, but to approach it positively, for by disclosing the sociology underlying knowledge itself, we are made more aware not to take things at face value, not even truth itself. (Web N. P)
\end{abstract}

It does appear, in the long run, that those who feel the jitters when relativism comes to the fore, forget that the world needs the individuality and particularity offered by a relativistic attitude to build bulwark against the mental castration created by a standardization that is itself a product of a few. What Kuhn and Feyerabend appear to be saying, and which I agree with, is that one requires more than theories and method to be part of a community of scientists. The rules and principles that guide one's choice of the theory or method, and which set the standards for justification of the choice, are not intrinsic to the theory or method. They must be sought outside them; they must be society-determined. Besides, Harris has voted for the relativism of the Goodman-type. According to him "Goodman's version of relativism is a relativity mild-mannered, one with little or no serious consequences for the traditional scientific and epistemological notions of rationality" (72). Again, this is stark-raving Western intellectual bigotry. Does the mere fact of a lack of "serious consequences" for traditional Western notion of rationality, secure the acceptance of a particular brand of relativism? Who is making the rules here? Once again, Harris's defense of Rationality Westerna Othrows it face down with a broken nose! That's exactly the point that Npostmodernists are making: you don't set the standards from your own pedestal, Бowith your own conceptual schemes, and then illegitimately legislate it as standard ๘for all cultures. 
If there is anything the postmodern attitude in science has done, it is to apply speed-breakers on the racing track of modern science, a break that ensures that modern science does not race into its own destruction. Somehow, postmodernism's speed breakers on the tracks of modern science have provided liberation for the models of knowing and given them a voice to be liberated from this modern authoritarianism.

This is why in, [African Philosophy Through Ubuntu], Mogobe B. Ramose insists that the way the colonized people conceive reality, knowledge and truth has been in the penitentiary of "European epistemological paradigm" and would need to be released in order to engender what he calls "a common, authentic and liberating universe of discourse". And to be candid, I agree with his insistence that "African philosophy contains an in eliminable liberative dimension". For him, "the imperative for the authentic liberation of Africa requires neither a supplicative apologia nor an interminable obsecious defense of being an Africa" (4). Part of the reason why I appreciate Ramose's work is the "liberating dimension" it pursues. For indeed Africans need mental liberation before Africa would be socio-economically liberated.

The postmodern hermeneutic cleaning of the cultural space of all the occupying tendencies of Western epistemological theories should be an entry point for Africa to demand to be heard- and in her own terms. This is why I suggested that African philosophers should quit "Reflection" and develop a "Refl-active" mentality. In my essay "The Principle of Refl-action" as the Basis for a Culture of philosophy in African", I had suggested that the need to create a culture of "philosophizing" in Africa can best be served by a principle that ensures that the African "thinks -to- do" (refl-acts) instead of the luxury of the armchair philosophy introduced by colonial education.

Modern science, with its concomitant rationality and method, should be conceived and perceived as just another mode of cognition. In her daring book, [The Earth Unchained. A Quantum Leap in Consciousness], Catherine Acholonu has noted that "Qantum Physics is a science that has proved classical scientists wrong and the philosopher right. Quantum mechanics is the science of the humanist, the psychologist, the philosopher, the mystic..." (69). At the level of "quanti", exactness disappears in science. After all, at the time when modern science was talking about a prescriptive methodology that would suffice all the sciences, there was only one fully developed science- physics, or more specifically, Newtonian Mechanics. But now, the discussion of methodology has O superseded the Newtonian type.

$\sim$ In an earlier paper, "The Mode of Knowledge in Science and Social ¿Science", I observed that under the influence of Ernst Mach, Karl Pearson etc.. A nnew idea emerged to the effect that science is merely an accurate description of the world. For Mach, it did not matter what method the scientists followed in 
describing as economically and as accurately as possible so as to be able to make predictions; what really mattered was that his predictions came out with a high probability. Also recent development in Cybernetics has shown that the traditional structure and method of science could not suffice the needs of contemporary science. Mach's Sensationalism, with its emphasis on sense data, has stimulated a new interest in the nature of the empirical evidence on which science is based. Albert Einstein's Theory of Relativity and developed quantum mechanics precipitated a new crisis in Physics. This crisis later generated the methodological doctrine of P. W. Bridgeman. Bridgeman formulated the theory known as Operationism or Operationalism, according to which the concepts employed in scientific theories, must be defined in terms of actual Operations carried out by the scientists in measuring their quantitative values. Rudolf Carnap advocated an inductive logic according to which the important thing about scientific propositions is that they are confirmable in terms of available evidence, while Karl Popper believes that science does not use the inductive method but rather uses the hypothetico-deductive method.

Contemporary discussions of methodology have a tendency to pass into metaphysical or epistemological considerations. Such discussions do not really affect theory choice by working scientists. The philosophical content of methodological enquiries has changed also. Instead of the search for a unique scientific method, the general conclusion seems to be that the method of science is an admixture of logical construction and empirical observation.

The capacity to be logical and empirical are not exclusive preserves of any one culture or people. Globalizing Western science marked the season of bondage for other narratives. Cahoone's characterization of the many conceptions or connotations of the goal of postmodernism becomes necessary when postmodernism is taken as a global topic. However, seen in its true postmodern pluralistic fashion, there is nothing preventing the Western intellectual from continuing to hang on to the "tattered flag of modernity"- as long as from the point of view of Africa, postmodernism is perceived in its liberating dimension. Indeed, it is both conceptually and practically impossible for a thorough- going modernist to embrace postmodernism.

In life, nothing is also absolute; sometimes we win some, sometimes, we lose some. Perhaps, relativism is the prize we must pay to appreciate the plurality of cultural space provided by the postmodernists. And indeed, what is really wrong with relativism? Why do we not complain about the fact that no two human beings have the same deoxyribonucleic acid (DNA)? Why do we attack Mrelativism so much in epistemology when it exists in bio-ontology? The popular Eocriticism of postmodernism which says that its rejection of a grand norm, if aaccepted as true, will also become a grand norm is an attempt to trivialize the substantial issues about modernity which postmodernity addresses. Besides, 
postmodernism, as the next-after of modernity is a useful continuation of the attempt to develop modern concerns.

Although, I share some of the views of Edwin Etieyibo about the release of philosophical discourses in Africa from the totalitarian and universalizing hegemony of the Enlightenment project, I have certain areas that I feel uncomfortable about his analysis. One, the fact that we are still struggling to explain the content and nature of the concept "African philosophy" appears to be a self-imposed challenge. If one goes through Sophie B. Oluwole's "The Africanness of a Philosophy" (1989) and Jim. I. Unah's "Can a Work Be Both African and Philosophy?" (2002) Problem of the Locution "African philosophy" unveils itself to us. For indeed, what makes a work in philosophy "African" becomes altogether difficult to decipher with any degree of exactness. On several occasions, I have argued that philosophy is a specific human activity and exists anywhere humans are. It is not a Western, African, Asian or Biafran activity, but it is found in the West, Africa, Asia, Biafra or wherever.

What we have called "African philosophy" or (imagine) "African Ethics" are nothing but philosophical or ethnical reflections in and for Africa. When systematic academic philosophy began in the West, it was not called "Western Philosophy". It was simply called "philosophy"!

Second, Etieyibo's identification of human-centeredness, prescriptivity and normativity as features of what he calls "African Ethics" and which make it "susceptible to the same sort of worries that post-modernity raises for modern thinking" (79) gives the impression that these features are exclusive to ethical discourses in Africa. But it is not so, before the advent of linguisticism in philosophy, Ethics was (and still remains largely) a normative discourse. Metaethics came later when philosophers, in their self- styled desire to remain relevant and "keep-communicating", decided to begin word-analysis. Although this may be necessary, but how significant does my coming to know the diverse meaning of the term "good" contribute to my being a good man? A careful reading of Etieyibo's essay, seems to place before those who reflect on Africa's realities a choice to make: either they accept postmodernism's pluralistic opening of the "cultural space" which provided them the platform to (at least) be heard in their own terms or remain in the foundational objective state imposed by their orientation and pedagogic introduction to Western philosophical thinking.

We cannot end this essay without a word on what is known as Transmodernity, a term coined in 1989 by the Spanish philosopher (and feminist) Rosa Maria Rodriquez Magda. Transmodernity is a dialectical passage from Mmodernity to postmodernity and then the transmodern Transmodernity is more of ofon attempt to salvage the best of modernity. It is the return and survival of the Epart of modernity that seems submerged by the invading radical relativism of postmodernism. Similarly, transmodernity is also post-modernity, but it is post- 
modernity without the tendency to rupture reality, albeit innocently. According to Enrique Dussel, in his essay "Transmodernity and Interculturality: An interpretation from the perspective of the philosophy of liberation", "Transmodernity points toward all of those aspects that are situated 'beyond" (and also 'prior to') the structure valorized by modern European/ North American Culture, and which are present in other non- European universal cultures, and have begun to move towards a pluriversal utopia" (19). The implication of the above is that, as a utopia, pluriversality keeps us always on the expectation for the best without losing hope.

Transmodernity believes that modernity is not even an exclusive WestEuropean phenomenon and argues that although colonialism may have ended, coloniality and its basic logic has remained. Transmodernity has a focus on the liberation of cultures that has long been under the epistemological hold of coloniality. What this means is that transmodernity is a dialectical synthesis of the opposition between modernity and postmodernity.

Philip Idachaba and Sylvester Ogba, in their essay "Decolonizing African Philosophy: Perspectives from Afro-Constructivism and Transmodernity" discuss the transmodern triune dialectical movement from "particulars to universals and then to Pluri-versals" (42-60). What makes their essay significant is that they discuss it against the backdrop of African Philosophy; that is they analyze the part that Transmodernity can play in the decolonization project/process within African philosophy.

For transmodernity, pluri-versality is a universal project. What this means, if we interpret it properly, is that instead of the "uni-versality" of modernity, or the ordinary plurality of postmodernity, there is a new tilt towards "pluri-versality". I am not, at this point, really concerned with a deep plunge into transmodernity. It will be the focus of further research, especially on its relationship to philosophical concerns in Africa. The implications of our discourse for Africa can range from the acquisition of a cultural space on the wings of postmodern thinking to the expression of ideas from a wide range of African thought-science, philosophy, art, etc., which were hitherto silenced by the roar of one universal reason. I simply would want to also point out that the dispute between modernists and postmodernists is no longer germane, it is now stale.

Modern science is no longer, ultimate wisdom.

Postmodern plurality appears to have been overtaken.

Transmordern pluri-versality is on the stage now and Africa surely has a lot of space on that stage! 


\section{Relevant Literature}

1.ACHOLONU, Catherine. O. [The Earth Unchained: A Quantum Leap in Consciousness], 1995. AFA Publications: Owerri. Paperback.

2.AGBO, Joseph N. "A Critique of the Critical Philosophy of Immanuel Kant”, [Flash: Journal of Philosophy and Religion], pp76-82, 2008. Vol 2. No 1. Paperback.

3.- . "Africa within the Globe: Confronting the Parameters of CrossCultural Philosophy”, [Journal of Cultural Studies], pp182-213, 2003. Vol 5. No 2. Paperback.

4.- . "Science and the 'End' of Epistemology: The Implications of the Postmodern Philosophical Hermeneutics for Africa”, [paper presented at the Bi-annual Conference of the Nigerian Philosophical Association (NPA), Benue State University, Makurdi], 12-15 May, 2010. U.P.

5.— . “On the Diction of Post-Modernists". U.P.

6.- . "the principle of 'Refl-action' as the Basic for a Culture of Philosophy in Africa", [Filosofia Theoretica: Journal of African Philosophy, Culture and Religions], pp423-460, July-December, 2013. Vol 2. No 2. Paperback.

7.- . "The Mode of Knowledge in Science and Social Science", [Philosophy and Logic, EZE Nwokereke Ed.], 2003. Jones Publications: Enugu. Paperback.

8. - .The Spectacles of Inter- Cultural Philosophy: Same frame, Different Lenses", [New Era Research Journal of Human, Educational and Sustainable Development], pp43-54, 2011. Vol 5. No 1. Paperback.

9.ALOZIE, Princewill I Ed. [History and Philosophy of Science, $2^{\text {nd }}$ edn.], 2001. Clear Lines Publications: Calabar. Paperback.

10. BAUN, Robert F. and FEYEREBEND, Paul. "Popper, Kuhn, Lakatos: A Crisis of Modern Intellect", [Science and Culture in the Western 
Tradition: Sources and Interpretations], 1987. Gorsuch Scarishrick: Arizona. Paperback.

11. BERTENS, Hans. [The Idea of A Postmodern: A History], 1995. Routledge and Kegan Paul: London. Paperback.

12. BLACKBURN, Simon Ed. [Oxford Dictionary of Philosophy], 1996. Oxford University Press: Oxford. Paperback.

13. CAHOONE, Lawrence E. [From Modernism to Postmodernism: An Anthology], 1996. Blackwell Publishers Ltd: Oxford. Paperback.

14. CHIMAKONAM, Jonathan O. [Introducing African Science: Systematic and Philosophical Approach], 2012. Author House: Bloomington. Paperback.

15. CHUA YI, Jonathan. "A postmodern Defense of Thomas Kuhn”. N. P. Retrieved $23^{\text {rd }}$ August, 2014. Web.

16. DUSSEL, Enrique "Transmodernity and Intercultuality: An interpretation from the Philosophy of Liberation". N. P. Retrieved $24^{\text {th }}$ August, 2014. Web.

17. ENYIMBA, Maduka. [The Fall of the Aristotelian and Ptolemaic System, Philosophy and the Rise of Modern Science, UDUIGWOMEN, Andrew F. Ed.], 2011. El- Johns Publishers: Uyo. Paperback.

18. ETIEYIBO, Edwin. "Postmodern Thinking and African Philosophy", [Filosofia Theoretica: Journal of African Philosophy, Culture and Religions], pp67-82, Jan-Jun, 2014. Vol 3. No 1. Paperback.

19. FEYERABEND, Paul K. [Against Method], 1975. Verso Press: New York. Paperback.

m20. - . [Farewell to Reason], 1987. Verso Press: New York. Paperback. 
21. - . "Reply to Criticism", [Boston studies in the Philosophy of Science, COHEN, R.S. and WARTOFSKY, M.W. Eds.], 1965. Humanities Press: New York. Paperback.

22. - . [Science in a free Society], 1978. New Left Books: London. Paperback.

23. GEURAS, Dean. "Richard Rorty and the Postmodern Rejection of Absolute Truth". N. P. Retrieved July 23, 2014. Web.

24. HARRIS, James F. [Against Relativism: A Philosophical Defense of Method], 1993. Open Court: Illinois. Paperback.

25. IDACHABA, Philip and OGBA, Sylvester. "Decolonizing African Philosophy: Perspectives from Afro-Constructivism and Transmodernity", [Frontiers of Knowledge in Philosophy: Cutting Edge Issues, ASIEGBU, Martins and CHUKWUOKOLO, Chidozie Eds.], pp42-60, 2014. Jones Publications: Enugu. Paperback.

26. KEKES, John. "Recent Trends and Future Prospects in Epistemology", [Meta-Philosophy], April to July, 1997. Vol 8. No 2. and 3. Paperback.

27. KUHN, Thomas S. [The Structure of Scientific Revolutions, $2^{\text {nd }}$ edn.], 1970. The University of Chicago Press: Chicago. Paperback.

28. - . "Reflections on My Critics", [Criticism and the Growth of Knowledge, LAKATOS Imre and MUSGRAVE, Alan Eds.], 1970. Cambridge University Press: Cambridge. Paperback.

29. KYMLICKA, Will. [Multicultural Citizenship], 1995. Clarendon Press: Oxford. Paperback.

$\Omega^{30 .}$ LAKATOS, Imre and MUSGRAVE, Alan, Eds. [Criticism and the M Growth of Knowledge], 1968. Cambridge University Press: Cambridge. \& Paperback. 
31. LYOTARD, Jean-Francois. "The Postmodern Condition", [After Philosophy: End or Transformation, BAYNES, Kenneth et al Eds.], 1987. MIT Press: Cambridge. Paperback.

32. NEWTON-SMITH, W. H. [The Rationality of Science], 1981. Routledge and Kegan Paul: London. Paperback.

33. OGUEJIOFOR, Obi J. "How African Is Communalism?", [Perspectives on African Communalism, ODIMEGWU, Ike F.H. Ed.], 2007. Trafford Publishing: Canada. Paperback.

34. OLUWOLE, Sophie B. "The Africanness of a Philosophy", [Readings in African Philosophy: An Anthology, OLUWOLE, S.B. Ed.], 1989. Maastech: Lagos. Paperback.

35. OZUMBA, Godfrey O. [The Philosophy of Logical Positivism and The Growth of Science], 2001. Bacos Publishers: Calabar. Paperback.

36. POPPER, Karl R. [Conjectures and Refutations: The Growth Of Scientific Knowledge], 1963. Routledge: London. Paperback.

37. - . [The Open Society and Its Enemies: Vol. 2 Hegel, Marx and the Aftermath Princeton], 1963. Princeton University Press: Princeton. Paperback.

38. - . [The Poverty of Historicism], 1957. Basic Books: New York. Paperback.

39. RAMOSE, Mogobe B. [African Philosophy through Ubuntu], 1999/2005. Mond Books Publishers: Harare. Paperback.

40. RORTY, Richard. [Philosophy and the Mirror of Nature], 1979. Princeton University Press: New Jersey. Paperback.

ڤิ41. RUSSELL, Bertrand. [History of Western Philosophy], 1971. George $\underset{\infty}{\infty}$ Allen and Unwin Ltd: London. Paperback. 
42. SAYER, Andrew. "Postmodernism and the Three 'Pomo' Flips", [Reason and Social Science], 2000. Sage Publications Ltd: London. Paperback.

43. SCHEFLER, Israel. [Science and Subjectivity], 1967. Hackett Publishers: Indianapolis. Paperback.

44. SPANOS, William. "De-struction and the Question of Postmodern Literature: Towards a Definition", [Par Rapport], 1979. Vol 2. No 2. Paperback.

45. SRIWARAKUEL, Warayuth. "Process Thought and Harmony", [Christianity, Culture and the Contemporary World: Challenges and New Paradigms, Alam Edward J. Ed.], 2009. Nortre Dame University Press: Louaize, Lebanon. Paperback.

46. UNAH, Jim I. [Essays On Applied Phenomenology], 2002. Foresight Press: Lagos. Paperback.

47. VANHOOZER, Kevin J. [Cambridge Companion to Postmodern Theology], 2005. Cambridge University Press: Cambridge. Paperback. 